\title{
A Proposed Study on the Impact of an Expressive Arts Elementary School through Ethnographic Interviews
}

\section{Belinda Smith}

For the past two decades the United States has seen major educational upheaval and discourse in search for educational improvement. Arts education at national, state, and local levels have been prominent in those initiatives accentuating how children are educated and assessed in the arts and the various styles and approaches of integrating the arts (Bresler, 1995, p. 31) through connection, correlation and integration with other disciplines (Snyder, 2001). John Goodlad, co-director of the Center for Educational Renewal at the University of Washington, points to education's need for initiatives of "renewal" in which individuals and groups seek improvement from within rather than "reform" which is driven by individuals and groups outside of what is to be changed. Thus "promoting the best in human attainment" in contrast to "promoting compliance" (2000, p. 14). He states, "Educational renewal and the arts need one another" and "that the epistemologies of the arts and school renewal mesh. There is a natural attraction" (p. 13). Amidst these educational debates, especially concerning curriculum, we have witnessed the issues surrounding poor test scores and high dropout rates as fuel in the search for alternatives to the traditional school model (Daniel, 2000). Today's adults experienced a traditional curriculum that is being questioned for today's youth. Mac Arthur Goodwin, past president of the National Art Education Association and national leader in arts education, believes that educational initiatives under renewal are: 1) curriculum framework implementation and the development of achievement standards and assessment and 2) alternative scheduling models. Goodwin places these initiatives "in the current context of increased local flexibility and local control, growing public 
demand for educational accountability, the emergence of charter schools, an increase in school choice, and the like" (1998, p. 20). The $35^{\text {th }}$ Annual Phi Delta Kappa Gallup Poll of Public Attitudes Towards Public Schools reveals high percentages that strongly demonstrate public concern that only relying on testing, as required in the No Child Left Behind Act, will mean less emphasis on art, music, history, and other subjects (NAEAnews, December, 2003, p.1). Taxpayers, teachers, and elected officials are searching for the most powerful approach to learning that will ensure a quality education for our youth. Can arts integration be part of the renewal we are looking for?

Interest in integration as a general concept has been in a fluctuating pattern since the early part of the twentieth century (Bresler, 1995; Tanner, 1989). Art education associations, higher education institutions, state departments of education, and local school boards have cited widespread support for advocacy of arts integrative curriculum beginning in the 1990's (Eisner, 1992; Krug, 2000; McLaughlin, 1990; Oddleifson, 1994). Craig Sautter, teacher-poet-writer at DePaul University in Chicago, reports that even though some innovative educational alternatives have been developed, "learning in, about, and through the arts" has great potential but has not been implemented as much as it should. He notes that:

\footnotetext{
Yet the arts have a favorable track record as a learning strategy. Years of experience among art educators and classroom teachers who use the arts to motivate and instruct students, thousands of successful artist-in-residence programs over the last 25 years, and a growing body of research in arts education all strongly suggest that education in and through the arts can play a significant role in changing the agenda, environment, methods, and effectiveness of ordinary elementary and secondary schools. (1994, p. 433)
} 
Visual arts, music, and movement have been integrated in learning programs successfully in preschool and kindergarten levels over the last two decades. Using the arts with other discipline areas is seen as a more natural way to help children connect their learning (Gallas, 1994; Grallert, 1991; Oddleifson, 1989). Specifically, Reggio Amelia preschools in Italy have been highly influential in the United States with their deep integration of the arts across the curriculum (Rabitti, 1991). In Reaching Potentials: Vol. 1. Appropriate Curriculum and Assessment for Young Children the National Association for the Education of Young Children states "Children's learning is not compartmentalized or divided into artificial subject-matter distinctions. The purpose of integrating curriculum is to reflect the natural way children learn" (Bredekamp \& Rosegrant, 1992, p. 21).

In elementary grades and beyond, integrated programs are used less extensively due to traditional structure and lack of teacher collaboration time. Even so, over the last decade there has been a tremendous increase in arts-infused schools from elementary to middle school levels (Daniel, 2000). When implemented, these alternatives to traditional curriculum delivery are seen as a change from the divisive role that isolated periods of art, math, music, reading, social studies, and science play. Instead, integrating the arts with other fields of disciplines is used as a method of helping children develop deeper understandings of their social and cultural surroundings and allows for a connectedness to reflect a natural way for children to learn (Aulgur, 1997; Corn, 1993; Daniel, 2000; Krug, 2000). Educational initiatives such as National Standards for Arts Education (CNAEA, 1994) and the Goals of 2000 (U.S. Department of Education, 1994) contain interdisciplinary components. The U.S. Department of Education's Report on Charter 
Schools (2000) stated that the number of arts-infused charter schools was growing and more accessibility to state and federal grants for start-ups was available. There is growing research that documents better academic performance by students attending artsinfused schools than students in schools with no emphasis in the arts (Catterall, 1998; McLaughlin, 1990; Dean \& Gross, 1992).

Yet, despite what appears to be support for a "renewal" of education in the United States through the arts (Aprill, 2001; Daniel, 2000; Eisner, 1992; Goldberg, 1992; Donmoyer, 1995), there are few descriptive or analytical examinations of working examples of arts integrative schools in operation for at least a decade. "Not enough studies of the very successful arts-integrated schools that dot the nation have been conducted" (Sautter, 1994, p. 435).

\section{Statement of Problem}

In building cases for arts integration, educators and philosophers present the virtues of arts integration in general. However, few report on feelings and responses of teachers and specifically the students and parents of arts integrated school programs that have been in progress for at least a decade (Aprill, Burnaford, \& Weiss, 2001, p.8). Many thematic integration development booklets are available and a few books have been recently published on arts integration which are: Integrating the Arts Across the Elementary School Curriculum (2004), Arts and Learning (2001), Thinking Through the Arts (2000), Renaissance in the Classroom (2001), and The Arts as Meaning MakersIntegrating Literature and the Arts throughout the Curriculum (1999). Compared to research in other areas of education, research on the effects of arts integration falls short. Craig Sautter (1994) states, "From the point of view of reform, there is simply not 
enough time to gather another decade's worth of research. The record so far is positive enough to justify creating more arts-integrated schools right now" (p. 453).

For this study, ethnographic interview data will be collected from former students and parents of an expressive arts elementary school in order to examine their perceptions of those school experiences. A list of students, now completing the eighth grade, and their parents will be compiled with the assistance of a parent from this population. I am hopeful that approximately fifteen to thirty families can be located as participants from a population of approximately fifty. After being a participant observer in the school's setting for nearly three years, I have established a long-term relationship of shared experiences with the current students, teachers, and parents.

The main instrument for the proposed study will be ethnographic interviews with questions falling into three categories: 1) descriptive, 2) structural, and 3) asking about contrasts (Spradley, 1979). The constant comparative method for analyzing interview data will be well suited for this particular inquiry by comparing one segment of data with another to determine similarities and differences (Merriam, 1998, p. 18). To enhance internal validity, I will employ four basic strategies: triangulation, member checks, longterm observation, and peer examination. The following questions will guide this study and specific interview prompts: Primary Question: What lasting effects do former students and their parents report regarding their expressive arts elementary school program? Sub-questions:

1. How do students and parents perceive this expressive arts elementary curriculum and its delivery in reference to other elementary schools?

2. What influenced parents' and students' decisions to attend this school? 
3. Did this expressive arts elementary school support the development of cognitive, emotional or affective skills? How were they developed and encouraged?

4. What creative art processes, visual thinking through art making, were students involved in during their elementary years? Did they have opportunities to apply these since the elementary years?

5. How were students involved in the arts during their elementary years?

6. How are students currently involved in the arts?

7. How do students see themselves involved in the arts in the future?

8. Would students or parents recommend this expressive arts elementary school program to other students and educational planners?

9. How do students view the arts as a motivation factor in this expressive arts elementary school program?

Four foundational concepts that guide arts integrated school programs will also guide this study. They are 1) Brain Research and Emotions, 2) Gardner's Theory of Multiple Intelligences, 3) Bloom's Taxonomy of Thinking Skills, and 4) Transmediation.

Recent movement toward and support for arts integrated, interdisciplinary, or artinfused curriculum has been sparked by several underlying theories concerning the brain and learning. Current brain research supports implications on how children can learn more effectively if taught through the use of emotion, different senses, pattern finding, and promotion of self-direction and social learning (Coleman, 1995; Rettig \& Rettig, 1999). Williams, author of Teaching for the Two-Sided Mind (1983), believes children are predominately asked to use "school-based reality", which focuses on words, reason, 
logic, and analysis. She contends that their "perspective reality", which uses artistic symbol systems, is a bigger part of reality and that we must encourage them to use and develop both types of thinking. In Arts with the Brain in Mind (2001), Jensen states, in part, "...the arts enhance the process of learning. The systems they nourish which include our integrated sensory attentional, cognitive, emotional, and motor capacities are in fact the driving forces behind all other learning...” (p. 58). Coleman's Emotional Intelligence (1995) explains that we have two minds - a thinking mind and feeling mind. Since the emotional brain is the first to receive input, we are more likely to recall information when learning is embedded in an emotional context (Rettig \& Rettig, 1999).

One of the strongest validations for the inclusion of the arts in the educational process has appeared in the form of the theory of multiple intelligences developed in 1983 and advanced by the Harvard psychologist Howard Gardner. Gardner's Frames of Mind: The Theory of Multiple Intelligences (1995) challenges the traditional view of intelligence as a unitary capacity measured simply by IQ tests and based solely through analysis and reason. Instead, Gardner's theory contends that humans possess at least eight mental abilities or areas of intelligence, each of which is related to a specific area of the brain. Each area of intelligence has three components: 1) the ability to create an effective product or offer a service that is valuable to the individual's culture, 2) skills needed to solve problems encountered in life, and 3) the potential to find or create solutions for problems which facilitate the acquisition of new knowledge. By assigning the arts as several of these intelligences, their intrinsic worth and importance in the learning process is further recognized.

Research has shown that teaching methods utilizing and developing the multiple 
intelligences encourage the use of higher order thinking and can provide a framework for effective teaching and learning. Preservice through veteran teachers are encouraged and trained to engage their students in lessons that proceed to higher order thinking. The correlation between Bloom's Taxonomy and Gardner's Multiple Intelligences is demonstrated by student observable behaviors that proceed from lower to higher order thinking.

$\begin{array}{lc}\text { Knowledge } & \text { higher order } \\ \text { Comprehension } & \text { thinking } \\ \text { Application } & \\ \text { Analysis } & \downarrow \\ \text { Synthesis } & \\ \text { Evaluation } & \end{array}$

Use of arts integration provides a curriculum delivery that encourages and motivates student learning and thinking. The identification of the need for higher-order thinking skills (Bloom, 1956) through authentic assessment is considered a major goal for education and encouraged in schools that are arts-infused (U.S. Department of Education, 1992; McLaughlin, 1990).

Transmediation is the process by which students transfer meaning from one media to another and causes students to consciously reflect on their learning while proceeding to the higher orders of thinking: knowledge, comprehension, application, analysis, synthesis, and evaluation. In order for transmediation to occur, "the correlation of content and expression in one sign system must be taken as an object of thought, then projected onto the expression plane of the new sign system" (Harste, J., 1990, p. 389). Integrating the arts into the curriculum encourages students to transmediate knowledge through an additional symbol system and provides students opportunities to engage in more flexible, higher-level thinking, creative problem-solving, and self-directed activity. 


\section{Significance of Study}

The expressive arts elementary school focused on in this study gives its students many ways to express and make personal connections. The school goes beyond providing more than the traditional time for the arts, but in addition "uses the arts as a means to connect all areas of the curriculum and to make the learning experience a coherent one that makes more sense to students" (Sautter, 1994). The curriculum is infused with the arts--dance, drama, music, and visual arts and thus allows expression and opportunities to learn and demonstrate knowledge through a variety of communication forms. From the student's point of view, there is concentration on an active process-oriented construction of skills. During the expressive arts school's origin and development, the arts focus was chosen due to the following reasons:

1. The school had an existing partnership with a nearby college (noted for dance and acting) by sharing facilities and students.

2. The faculty expressed strong beliefs in whole language theory and valued self expression.

3. The diverse student population (varied racial and economic backgrounds, English as a Second Language classes, and Title I Funding) could benefit from learning through the arts and through their different modalities.

This expressive arts elementary program model incorporates the following four components:

1. The language arts program emphasizes creative writing and literature.

2. There is additional time in the weekly schedule for art and music to be used for integration of curriculum (270 minutes per week). 
3. Enrichment classes in the arts are conducted both before and after school.

4. An artists-in-residence program is actively employed (four 6-8 week sessions).

The proposed research on parents' and students' perceptions on this type of school program can offer insight for other schools, communities, and educators seeking to renew and/or construct a successful arts integrative curriculum.

\section{References}

Aprill, A., Burnaford, G., \& Weiss, C. (2001). Renaissance in the classroom: Arts Integration and meaningful learning. Mahwah, NJ: Lawrence Erlbaum Associates, Publishers.

Aulgur, L. (1997). First and second graders coming to know: The role of students and teachers in an expressive arts school. (Doctoral dissertation, University of Missouri, Columbia, 1997). Dissertation Abstracts International, 59-07, A, 2319.

Bloom, B. (Ed.). (1956). Taxonomy of educational objectives: The classification of educational goals, handbook I: cognitive domain. New York: David McKay.

Bredekamp, S. \& Rosegrant, T. (Eds). (1992). Reaching potentials: Vol. 1. Appropriate curriculum and assessment for young children. Washington, D.C.: National Association for the Education of Young Children.

Bresler, L. (1995). The subservient, co-equal, affective, and social integration styles and their implications for the arts. Arts Policy Education Review, 96(5), 31-37.

Catterall, J. (1998). Does experience in the arts boost academic achievement? A response to Eisner. Art Education, 51(4), 6-8.

Coleman, D. (1995). Emotional Intelligence. New York, NY: Bantam Books.

Consortium of National Arts Education Associations (CNAEA). (1994). National standards for arts education: What every young American should know and be able to do in the arts. Reston, VA: Music Educators National Conference.

Corn, A. (1993). Arts integration and curricular change: A case study of five first and second grades. Unpublished doctoral dissertation, University of Missouri, Columbia.

Daniel, R. (2000). The right staff: The true key to arts-focused schools of choice. Arts Education Policy Review, 101, 6, 33-37. 
Dean, J. \& Gross, I. (1992). Teaching basic skills through art and music. Phi Delta Kappan, 73(8), 613-618.

Donmoyer, R. (1995). The arts as modes of learning and methods of teaching: A (borrowed and adapted) case for integrating the arts across the curriculum. Arts Education Policy Review, 96(5), 14-19.

Eisner, E. (1992). The misunderstood role of the arts in human development. Phi Delta Kappan, 73(8), 591-595.

Eisner, E. (2003, April). What constitutes credible research in visual art education?, Guest lecturer-Critical Links Discussion. Conducted at National Art Education Association Annual Conference, Minneapolis, MN.

Gallas, K. (1994). The languages of learning: How children talk, write, dance, draw, and sing their understanding of the world. New York, NY: Teachers College Press.

Gardner, H. (1995). Frames of mind: The theory of multiple intelligences. $10^{\text {th }}$ anniversary edition, New York: Basic Books.

Gelineau, R. (2004). Integrating the arts across the elementary school curriculum. Belmont, CA: Wadsworth/Thomson Learning.

Goldberg, M. (2001). Arts and learning: An integrated approach to teaching and learning in multicultural and multilingual settings. San Francisco, CA: Addison, Wesley, Longman, Inc.

Goldberg, M. (1992). Expressing and assessing understanding through the arts. Phi Delta Kappan, 73(8), 619-623.

Goodlad, J. (2000). Educational renewal and the arts. Arts Education Policy Review, 101(4), 11-14.

Goodwin, M. (1998). Reaching a strategic inflection point: Current education reform initiatives and arts education. Art Education Policy Review, 100(1), 20-26.

Grallert, M. (1992). Working from the inside out: A practical approach to expression. In M. Goldberg \& A. Phillips (Eds.), Arts as education (pp. 70-90). Cambridge, MA: Harvard Educational Review, Reprint Series No. 24.

Harste, J. (1990). Creating classrooms for authors. Portsmouth, NH: Heinemann. Jensen, E. (2001). Arts with the Brain in Mind. Alexandria, VA: Association for Supervision and Curriculum Development.

Krug, D. \& Cohen-Evron, N. (2000). Curriculum integration positions and practices in art education. Studies in Art Education, 41(3). 258-275. 
McLaughlin, J. (Ed.). (1990). Building a case for arts education: an annotated bibliography of major research. Lexington, Kentucky: Kentucky Alliance for Arts Education.

Merriam, S. B. (1998). Qualitative research and case study applications in education. San Francisco, CA: Jossey-Bass Publishers.

National Art Education Association News, December, 2003, Vo. 45, No. 6, Circulatedas a public service from Phi Delta Kappan, September 2003, p. 41-56.

Oddleifson, E. (1989). A proposal for an arts education demonstration project. Hingham, MA: The Center for Arts in the Basic Curriculum.

Oddleifson, E. (1994). What do we want our schools to do? Phi Delta Kappan, 75(6), 446-453.

Rabitti, G. (1991). Preschool at La Villetta, Reggio Emilia, Italy. M.A. thesis in Education, University of Illinois, Champaign.

Rettig, J. \& Rettig, P. (1999). Linking brain research to art. Art Education, 52(6), 18-24.

Sautter, C. (1994). An arts education school reform strategy. Phi Delta Kappan, 75(6), 433-437.

Schiller, W. (2000). Thinking through the arts. The Netherlands: Harwood Academic Publishers.

Snyder, S. (2001). Connection, correlation, and integration. Music Educators Journal, 87(5), 32-39, 70.

Spradley, J. (1979). The ethnographic interview. New York: Holt, Rinehart and Winston.

Tanner, D. (1989). A brief historical perspective of the struggle for an integrative curriculum. Educational Horizons, 68(1), 7-11.

U.S. Department of Education. (1992). SCANS, Secretary's commission on achieving necessary skills. Washington, D.C.: U.S. Department of Education.

U.S. Department of Education. (1994). Goals 2000: Educate America. Washington, D.C.: U.S. Department of Education.

U.S. Department of Education. (2000). Report on charter schools. February, 2000. Washington D.C.: U.S. Government Printing Office.

Williams, L. (1983). Teaching for the two-sided mind: a guide to right brain/left brain Education. Englewood Cliffs, N.J.: Prentice-Hall. 